\title{
Cambrian shelf deposits of the King Square Formation, Saint John Group, southern New Brunswick
}

\author{
Saifullah K. Tanoli* and Ron K. Pickerill \\ Department of Geology, University of New Brunswick \\ Fredericton, New Brunswick E3B 5A3, Canada
}

Date Received July 5, 1988
Date Accepted December 7, 1988

\begin{abstract}
The upper Middle Cambrian to early Late Cambrian King Square Formation, Saint John Group, southem New Brunswick, is an approximately $\mathbf{3 8 0} \mathrm{m}$ thick silicilastic sequence of interbedded fine-grained sandstones and siltstones and shales. On the basis of sandstone to shale/siltstone ratios, bed thickness and characteristics, sedimentary structures and degree of bioturbation three lithofacies are recognized. These are facies KS1, thin bedded sandstone and shale lithof acies; KS2, thick bedded sandstone lithofacies; and KS3, bioturbated shale and siltstone with interbedded sandstone lithofacies. These lithofacies are interpreted to have been deposited on a wave- and storm-influenced marine subtidal shelf. Facies KS1 was deposited essentially below wave base though in its upper horizons, deposition may have occurred above storm wave base. Facies KS2 was essentially deposited in a shallower subtidal inner- to mid-shelf environment above storm wave base and facies KS3 initially above and latterly below storm wave base. The exact nature of the currents responsible for transportation and deposition of the storm-related sandstones (geostrophic flows or turbidity currents) is impossible to determine and therefore palaeocurrent data must be interpreted with caution. The stratigraphic arrangement of the lithofacies, with facies KS1 being the oldest and KS3 the youngest, suggests that the King Square Formation represents a regressive-transgressive sequence.
\end{abstract}

La Formation de King Square (Groupe de Saint John, Nouveau-Brunswick, fin du Cambrien moyen-début du Cambrien tardif) est une série terrigène d'environ $380 \mathrm{~m}$ d'épaisseur, constituée d'un interlitage de grès fins, de siltstones et de shales. Les rapports grès/shale et grès/siltstone, les caractéristiques et l'épaisseur des lits, les structures sédimentaires ainsi que le degré de bioturbation permettent de reconnaître trois lithofaciès. Ce sont les faciès KS1 (grès et shale finement lités), KS2 (grès en bancs épais) et KS3 (grès interlité de shale et siltstone bioturbés). On interprète ces lithofaciès comme ayant été déposés sur une plateforme marine subtidale influencée par la houle et les tempêtes. Le dépôt du faciès KS1 s'effectua essentiellement sous la zone d'amortissement de la houle quoique ses horizons supérieurs puissent refléter une sédimentation au-dessus de la profondeur d'amortissement des ondes liées aux tempêtes. Le milieu de dépôt du faciès KS2 correspond à un site moins profond, soit la plateforme infralittorale interne ou moyenne, exposée à l'action des ondes de tempêtes. Le dépôt du faciès KS3 débuta au-dessus de la profondeur d'amortissement des ondes liées aux tempêtes et continua en-dessous de celle-ci. On ne peut guère déterminer la nature exacte des courants géostrophiques ou de turbidité responsables du transport et du dépôt des grès liés aux tempêtes; la prudence est donc de mise lors de l'interprétation des données sur les paléocourants. Le faciès KS1 étant le plus ancien et le faciès KS3 le plus récent, l'agencement des lithofaciès suggère que la Formation de King Square représente une série d'abord régressive puis transgressive.

[Traduit par le journal]

\section{INTRODUCTION}

Despite the considerable research undertaken over the last decade or so on modern and ancient wave- and storm-dominated shelf sequences, many aspects are not clearly and fully understood. Such enigmas result from the complex nature of shelf processes (Johnson and Baldwin, 1986), the general lack of modern epeiric seas, which were more common in the past (Duke, 1985), and the rarity of severe storm or hurricane events, considered by most researchers (see Walker, 1984) to be responsible for sand transport on storm-dominated shelves. Turbidity currents (Walker, 1983), rip currents (Hayes, 1967) and windforced and storm-surge ebb currents deflected by Coriolis forces to produce geostrophic currents (Morton, 1981; Swift et al., 1986) have each been emphasized as responsible agents for sand transportation on such shelves but the debate still continues (see Swift et al., 1986; Duke, 1987).

In this paper we describe a sequence of siliciclastic strata from the Cambrian of southern New Brunswick and which we interpret as having been deposited on a wave- and storm-influenced shelf. Unlike many previously described ancient storminfluenced shelf sequences (see Duke, 1985 for review) hum-

*Present address: Department of Geology, University of Peshawar, Peshawar, Pakistan 
mocky cross-stratification (Harms et al., 1975), regarded by many as diagnostic of storm activity (but see Swift et al., 1983; Klein and Marsaglia, 1987), though present, is uncommon. This supports the conclusion of Kreisa (1981) that no single model or sequence of sedimentary structures fit all shelf hydrodynamic regimes and sediment types, particularly in the geologic record.

\section{LOCATION AND GEOLOGIC SETTING}

The King Square Formation of Tanoli and Pickerill (1988) is the thickest (up to $380 \mathrm{~m}$ ) and most widely exposed unit of the Cambrian to early Ordovician Saint John Group of southern New Brunswick, and is upper Middle Cambrian to early Late Cambrian in age. Essentially, the formation consists of a sequence of interbedded fine-grained sandstones and siltstones and shales. Exposures are centered in and surrounding the vicinity of the city of Saint John in five main areas (Fig. 1) in a series of northeast trending, tightly folded, en echelon basins. These areas are (Fig. 1):- (i) in and within the suburbs of the city of Saint John; (ii) along Ratcliffe Brook in the Loch Lomond area, ca. $45 \mathrm{~km}$ northeast of Saint John; (iii) on Catons Island in the Long Reach; (iv) at Musquash Head along the coast of the Bay of Fundy; (v) along the Hammond River, ca. $45 \mathrm{~km}$ northeast of Saint John. Of these, Musquash Head exposes severely deformed strata and Catons Island only a relatively small and incomplete stratigraphic sequence; therefore, the ensuing discussion is centred on those exposures in the remaining three areas. No single outcrop exposes the complete stratigraphic sequence of the King Square Formation and the estimated thickness of $380 \mathrm{~m}$, obtained from within the city of Saint John, was derived essentially from map interpretation.

\section{LITHOFACIES}

We have divided the King Square Formation into three lithofacies, herein termed facies KS1-3, on the basis of sandstone to shale/siltstone ratios, bed thickness and characteristics, sedimentary structures, and the degree of bioturbation. Facies KS1 and KS2 are more widely and better exposed in the Saint John area while facies KS3 is better exposed along Hammond River (Fig. 2). Despite structural complexities, relationships of the lithofacies to other stratigraphic units of the Saint John Group

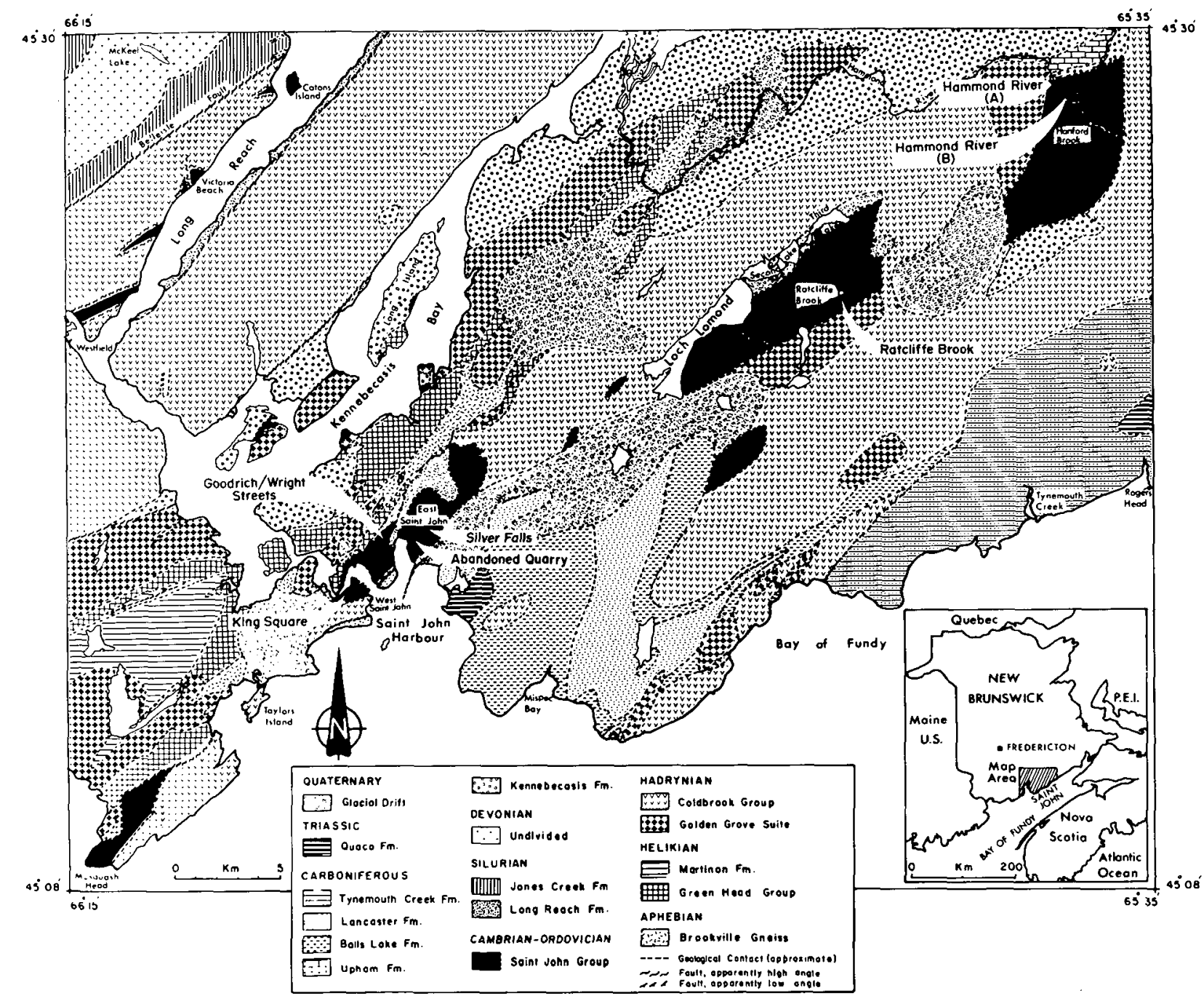

Fig. 1. Simplified geological map of southern New Brunswick showing generalized distribution of the Saint John Group and location of the main sections of the King Square Formation as referred to in the text (modified after Tanoli and Pickerill, 1988). 


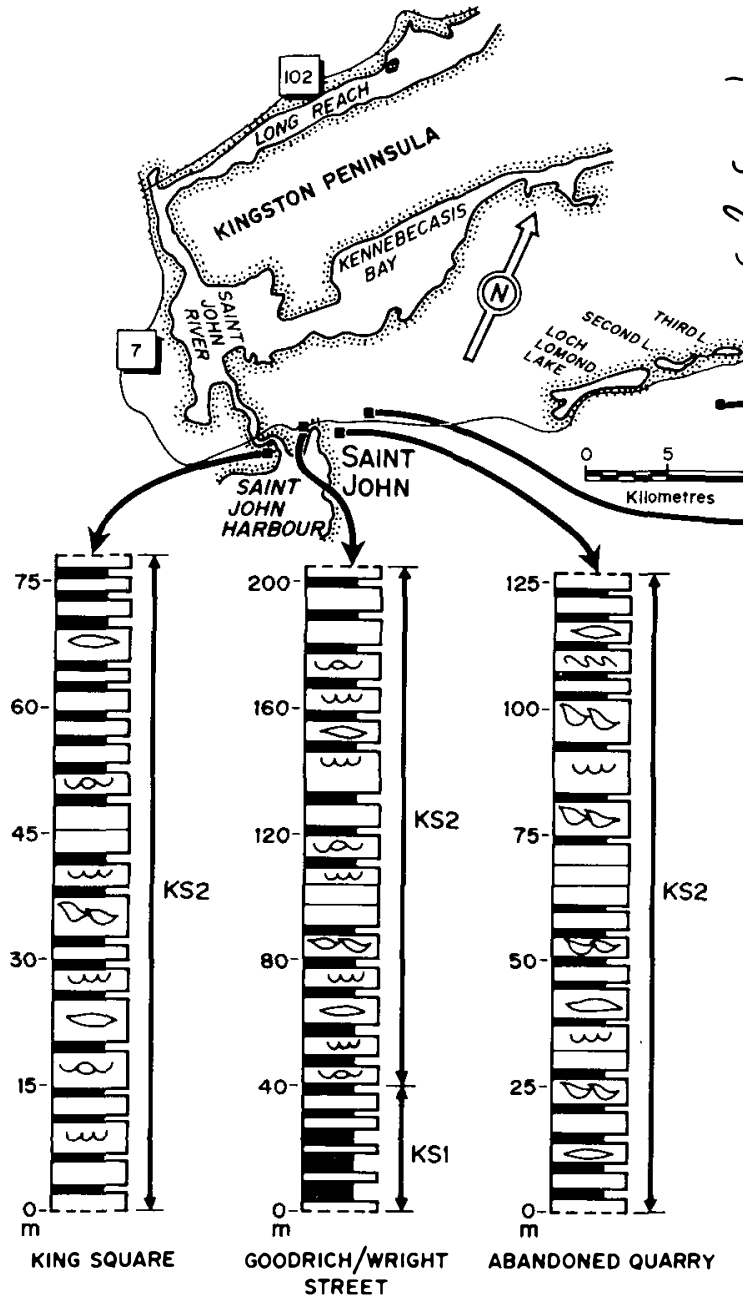

\section{LEGEND}

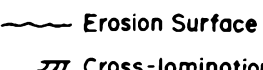

a Interference Ripple Marks

N Asymmetrical Ripple Marks

W symmetrical Ripple Marks
D Ball and Pillow Structures

$O$ Lenticular Bedding

os Limestone Nodules

$\square$ Limestone Beds

Biofurbated Shale

Non-bioturbated Shale

Fine-grained Sondstone

Amalgamated Beds

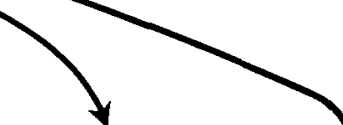

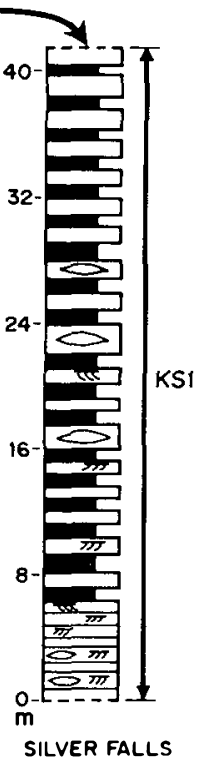
IIII iii)

40

32-

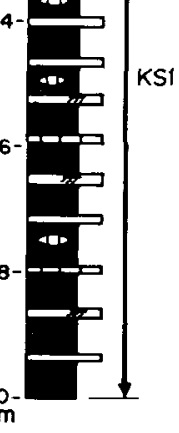

RATCLIFFE BROOK
12.5 -

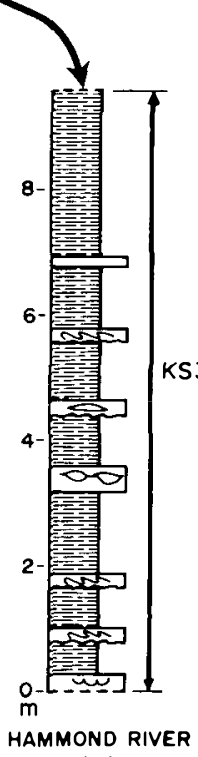

(B)

Fig. 2. Measured stratigraphic columns of the major sections of the King Square Formation with lithofacies distribution. Broken lines at the base or top of individual sections indicate unexposed lower or upper contacts respectively. Solid line at the base of the section at Ratcliffe Brook represents lower exposed contact. Section (A) at Hammond River is below the bridge near the intersection of H.W. 820 and H.W. 111 ; section (B) is ca. $1 \mathrm{~km}$ downstream from this bridge.

demonstrate that facies $\mathrm{KS} 1$ is the oldest and $\mathrm{KS} 3$ the youngest and all form part of an essentially regressive-transgressive sequence.

\section{Facies KS1 - Thin bedded sandstone and shale lithofacies}

\section{Description}

Characteristically, facies KS1 comprises fissile shale with siltstone laminae, which is generally non-bioturbated, and interbedded (rarely up to $40 \mathrm{~cm}$, typically $2-10 \mathrm{~cm}$ thick), grey, finegrained sandstone beds with sharp upper and non-erosive or erosive lower contacts (Fig. 3). At some localities, such as at Ratcliffe Brook, limestone nodules are present. The sandstone to shale ratio generally increases stratigraphically upward from approximately $30 \%$ sandstone in the lower horizons to up to as much as $70 \%$ in the upper levels. There is a corresponding vertical increase in thickness of the sandstone beds. Additionally, some of the thicker sandstones in the upper horizons of this facies thicken and thin laterally and even become lenticular or wavy (cf. Reineck and Wunderlich, 1968; Reineck and Singh, 1980) (Fig. 3). Sandstone beds may be massive, entirely parallellaminated or may possess parallel-passing vertically into current ripple cross-lamination (Fig. 3b). Although the interbedded shales are generally non-bioturbated, some of the sandstone soles preserve rare examples of the trace fossils Gordia, Palaeophycus, Paleodictyon and Taenidium.

This facies constitutes the basal part of the King Square Formation. Its lower contact is exposed in the bed of the stream at Ratcliffe Brook and at Cold Brook where it is gradational with the underlying Forest Hills Formation. At other localities the contact is unexposed but is inferred to be gradational. The facies passes gradationally into facies $\mathrm{KS} 2$ without any sharp change in lithology; its upper boundary is placed where the proportion of sandstone reaches $70 \%$. Determination of its exact thickness is hampered by incomplete exposures due to coverage by construction or vegetation and additionally by structural complexities. Nevertheless, along Goodrich Street (Fig. 1) the estimated thickness is about $80 \mathrm{~m}$, and, based on map interpolation, more or less similar thicknesses are estimated for other localities. 

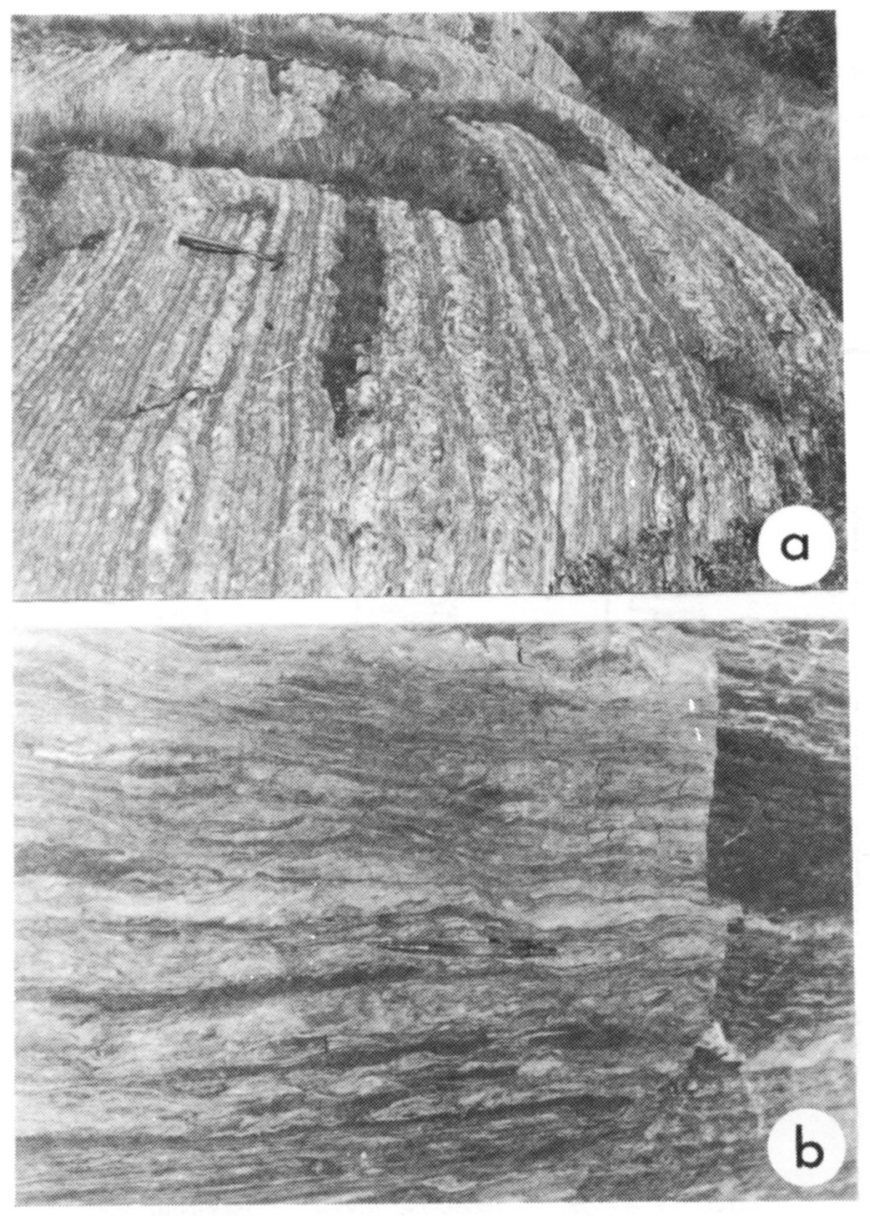

Fig. 3. Facies KS1 at Silver Falls, Saint John. (a) Interbedded shale and sandstone beds. Length of hammer is $32 \mathrm{~cm}$. (b) Laterally pinching and swelling of cross-laminated sandstone layers which in several examples result in discontinuous lenses. Length of pencil is $13.5 \mathrm{~cm}$.

\section{Interpretation}

Features of this facies suggest formation in a generally low energy shelf environment where chiefly muddy sediments accumulated. The generally non-bioturbated nature of the shales suggests relatively high sedimentation rates or unfavourable conditions (e.g., low oxygen) for colonization by most benthic organisms and therefore possibly relatively deep water. Presumably the muds were deposited from suspension from material introduced by wave and, or, current activity (cf. Simonson, 1984; Swift et al., 1986) during 'fair-weather' conditions. The interbedded fine-grained sandstone beds are best interpreted as having been periodically introduced by relatively higher energy storm-related currents (cf. De Raff et al., 1977; Brenchley et al., 1979; Kreisa, 1981; Morton, 1981; and many others). As previously outlined, however, the transporting mechanism(s) of the sands is problematic as, particularly in present-day shelf areas, the processes leading to sand deposition are complex and varied with different authors emphasizing different environmental parameters (see Swift et al., 1979, 1983, 1986; Morton, 1981; Nelson, 1982). While the processes themselves are com- plex and varied, research on many ancient shelf sequences (e.g., Brenner and Davies, 1973; Goldring and Bridges, 1973; Bourgeois, 1980; Simonson, 1984; Aigner, 1985; and many others) does suggest a direct relationship between bed thickness and increasing distance from source; that is, in shallower more proximal environments, beds are typically thicker than their counterparts in deeper more distal regimes. This might suggest, therefore, that sandstones of facies KS1 were formed distal to source and perhaps in relatively deep water. Certainly there is no evidence of wave activity in the sandstone beds thus suggesting deposition below even storm wave base. This is further emphasized by the absence of amalgamated beds, internal erosion surfaces and the presence only of massive, parallel-and current cross-laminated beds (cf. Brenchley et al., 1986).

The general increase in thickness and frequency of the sandstone beds stratigraphically upwards suggests a shallowing trend, particularly when considered in association with the directly overlying facies KS2 which can be convincingly demonstrated as having formed above storm wave base. The exact position on the shelf is difficult to determine because no coeval shoreline or slope and basin equivalents are known from the Saint John Group, and the shelf gradient, width and precise position of the ancient shoreline are all unknown parameters. Present-day mud-dominated shelves may occur in a variety of scenarios, ranging from inner- to outer-shelf environments (Stanley $e t$ al., 1983; McCave, 1985) and therefore comparison with modern shelves in terms of a specific environment is meaningless. However, because the overlying facies KS2 was deposited in a shallower subtidal environment above storm wave base, it can perhaps be suggested that this facies was deposited in at least a mid-shelf, possibly deeper, regime.

\section{Facies KS2 - thick bedded sandstone lithofacies}

\section{Description}

This facies characterizes the middle part of the King Square Formation and is the most widely exposed, the thickest continuous sequence being more than $160 \mathrm{~m}$ thick (Fig. 2). The facies is distinguished from the underlying facies $\mathrm{KS} 1$ and overlying facies KS3 by the presence of greater than $70 \%$ sandstone with respect to interbedded shale, which may or may not be bioturbated. The stratigraphically lower and upper portion of the facies are similar in that they possess thinner bedded sandstones and contain more shale (10-30\%) than the middle portion where shale is generally $10 \%$ or less.

In the central portions of this facies, amalgamated sandstone beds may be present (Fig. 4a) but more typically the beds are separated by thin (mm-cm thick) shale slivers (Fig. 4b). The sandstone is grey, fine-grained, and beds typically range between 10 and $70 \mathrm{~cm}$ in thickness. Lower bedding contacts may be planar, erosive and loaded; upper bedding surfaces are sharp and either planar or more typically marked by straight to sinuous crested symmetrical, symmetrical bifurcating, slightly asymmetrical, and complex interference ripple marks. The majority of ripples are clearly wave-formed in origin. Ripple spacing ranges between 5 and $12 \mathrm{~cm}$ and most possess rounded crests, though 

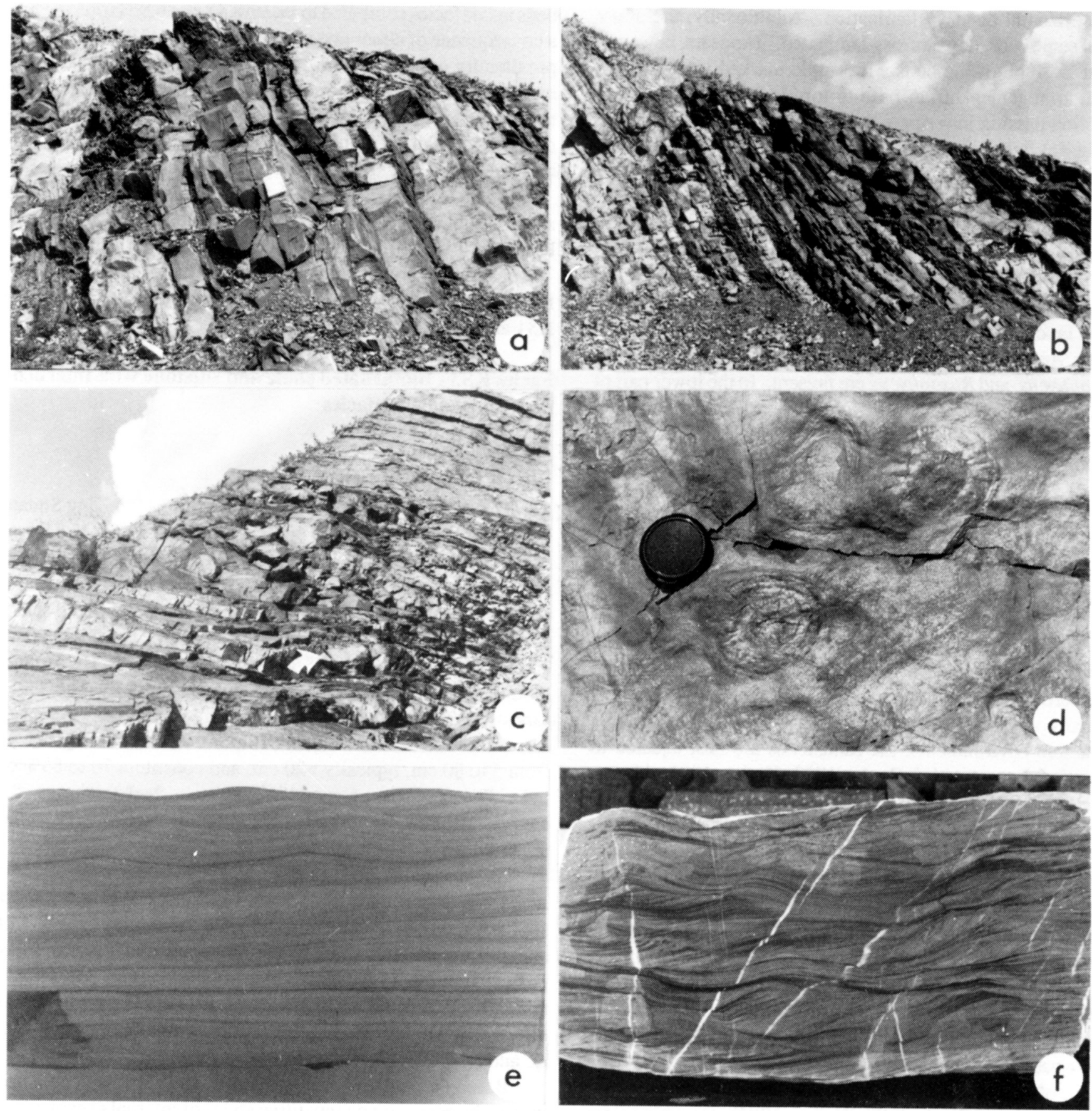

Fig. 4. Facies KS2. (a) Amalgamated sandstone beds in approximately the middle of the facies from the abandoned quarry in Saint John. Length of notebook is $19 \mathrm{~cm}$. (b) Predominant sandstone beds with rare thin shale partings more typical of the middle portion of the facies from the abandoned quarry in Saint John. (c) Lateral pinching and swelling of sandstone beds from the abandoned quarry in Saint John. Ball and pillow structures are common (e.g., arrowed). (d) Medusoids preserved on the upper surface of a rippled sandstone bed along H.W. 1 near Wright Street. Lens cap is $5.5 \mathrm{~cm}$ in diameter. (e) Polished slab of a sandstone bed from the abandoned quarry in Saint John exhibiting internal minor erosion surfaces and slightly wavy lamination in its lower portion and cross-laminated sets in its upper portion. Specimen is $11.5 \mathrm{~cm}$ thick. (f) Polished slab of a sandstone bed exhibiting essentially unidirectional cross-laminated and wavy-laminated sets throughout. Specimen from near the westem end of Union Street, south of the Goodrich - Wright streets locality. Specimen is $10.5 \mathrm{~cm}$ thick.

flattened ripple tops are also present. Rarely, wrinkle marks and brush marks are superimposed on the rippled surfaces. The beds commonly thicken and thin laterally (Fig. 4c), and rarely they pinch out completely. Moreover, several of the beds exhibit synsedimentary deformation features such as load and ball and pillow structures (Fig. 4c). Most of these appear internally structureless but in some of them, deformed laminae conform to the shape of the pillows.

Internal structures in all sandstone beds of facies KS2 are not conspicuous, probably as a result of weathering or the presence 
of apparently massive beds, but where evident consist of essentially horizontal or wavy lamination. Additionally, the upper parts of some beds may be cross-laminated. It appears, however, at least in some of the beds with ripple marked tops, that the general arrangement, from base to top, is horizontal or wavy lamination passing into ripple cross-lamination at and near the top (Fig. 4e). Internal organization in some beds is more complex and is marked by the combination of wavy laminae and crosslaminae (Fig. 4f). Grading within individual beds is not conspicuous but petrographic analysis suggests this to be a result of essentially unimodal grain size. Among the fossils, medusoids ((Fig. 4d) Pickerill, 1982), Agnostus pisiformis (Hayes and Howell, 1937), unidentifiable trilobite spines and abundant inarticulate brachiopods are present. Rare examples of trace fossils such as Arthraria, Cochlichnus, Cruziana, Didymaulichnus, Palaeophycus, and Rusophycus are present. In the lower part of the facies Monocraterion and Skolithos are particularly common.

\section{Interpretation}

Thickness and common amalgamation of the sandstone beds, the low proportion of shale, the presence of wrinkle marks, interference ripple marks, and flattened ripple tops suggest deposition in relatively shallow water conditions (cf. Goldring and Bridges, 1973; Reineck and Singh, 1972; Kumar and Sanders, 1976; Kreisa, 1981; Morton, 1981; Allen, 1985). The presence of typical shallow water trace fossils and abundant and large inarticulate brachiopods reinforces this conclusion. As with many other similar previously described facies from broadly comparable environments, the sandstones are best equated to storm-related currents (cf. Banks, 1973; Kreisa, 1981; Aigner, 1982; Rice, 1984; Brenchley, 1985; Fenton and Wilson, 1985; McCave, 1985; Handford, 1986). Hunter and Clifton (1982) have outlined three diagnostic criteria for interpreting similar sandstones as storm-related: (i) evidence of relatively strong flow before and during the first stages of deposition followed by decreasing flow strength, (ii) evidence of rapid deposition at a declining rate and (iii) evidence of oscillatory flow. In the sandstones of facies KS2 evidence of strong flow prior to deposition is suggested by the erosive bases of many of the sandstone beds. Initial rapid deposition is suggested by the massive nature of the lower portions of many of the beds and the presence of load and ball and pillow structures (cf. Anketell et al., 1970; Reineck and Singh, 1980; Walker, 1984). Declining flow strength is indicated by parallel-laminated passing vertically into cross-laminated horizons and oscillatory flow is indicated by the presence of wave-formed ripples on the upper surfaces of many beds.

Beds with complicated internal arrangement of mixed wavy and cross-laminae throughout are interpreted to indicate prolonged periods of wave-generated currents (cf. Kreisa, 1981). As noted above the apparent lack of normal grading in these sandstone beds, which is very characteristic of many storm-related sediments (e.g., Hayes, 1967; Reineck and Singh, 1972; Kumar and Sanders, 1976; Nelson, 1982; Allen, 1984), is interpreted as a result of the essentially unimodal fine-grain size source material.
The relatively low proportion of shale and thicker sandstone beds in this facies compared to facies KS 1 and $\mathrm{KS} 3$ is presumably a consequence of either one or a combination of factors, such as proximality to source, high sedimentation rates and shallower marine waters, where wave energy was sufficiently high enough to prevent settling of significant amounts of fine-grained sediments (cf. Goldring and Bridges, 1973; Kreisa, 1981; Hobday and Morton, 1984; Fenton and Wilson, 1985).

We therefore suggest that facies $\mathrm{KS} 2$ formed in a relatively shallow subtidal marine environment located above storm wave base in an inner- to mid-shelf environment (see also Allen, 1984). The observed characteristics, as described above, suggest that the facies was undoubtedly deposited in shallower water than facies $\mathrm{KS} 1$ and KS3.

Facies KS3 - Bioturbated shale and siltstone with interbedded sandstone lithofacies

\section{Description}

This facies constitutes the upper portion of the King Square Formation and is at least $50 \mathrm{~m}$ thick, probably more. The lower contact with facies KS2 is gradational (see previously) and the upper contact with the overlying Silver Falls Formation is unexposed. Lithologically, facies KS3 consists of bioturbated shale, siltstone and thinly bedded sandstone ( $\mathrm{mm}$ to $2 \mathrm{~cm}$ thick) interbedded with variably thick ( 5 to $40 \mathrm{~cm}$ ), typically 5 to $15 \mathrm{~cm}$, nonbioturbated, fine-grained sandstone (Fig. 5a, b). The latter sandstones constitute 15 to $30 \%$ of individual sections. Interbedded shale, siltstone and sandstone portions range in thickness from 5 to $80 \mathrm{~cm}$, typically $>20 \mathrm{~cm}$, and constitute 70 to $85 \%$ of individual sections. Generally, sandstone bed thickness decreases upwards. Bioturbation is commonly more intense in the upper portions of the facies.

The sandstone beds possess sharp and erosive bases and sharp, planar or rippled tops. Some pinch out laterally, but most are continuous, at least on outcrop scale. They may exhibit ball and pillow structures, are rarely slumped and several soles possess flute marks, some of which are loaded (Fig. 5d). Ripple marks include small scale symmetrical (Fig. 5f), symmetrical bifurcating, slightly asymmetric, strongly undulatory asymmetric and linguoid (Fig. 5e) varieties.

Based on field observations and many $(>50)$ slabs polished in the laboratory, seven repetitive styles of internal organization can be recognized in these sandstones. These are:-

(i) Convex-up hummock-like or concave-up swale-like lamination (cf. Harms et al., 1975), the upper surfaces of which may or may not be conspicuously reworked (Fig. 6a, b).

(ii) Basal massive portions passing vertically into horizontal lamination and in turn into current climbing ripple lamination (Fig. 6c).

(iii) Horizontal lamination passing vertically upward into current climbing ripple lamination (Fig. 6d).

(iv) Broadly wavy lamination passing vertically upward into slightly inclined or horizontal lamination which in turn passes into low-angle unidirectional cross-lamination and then into climbing ripple cross-lamination before passing into bidirec- 

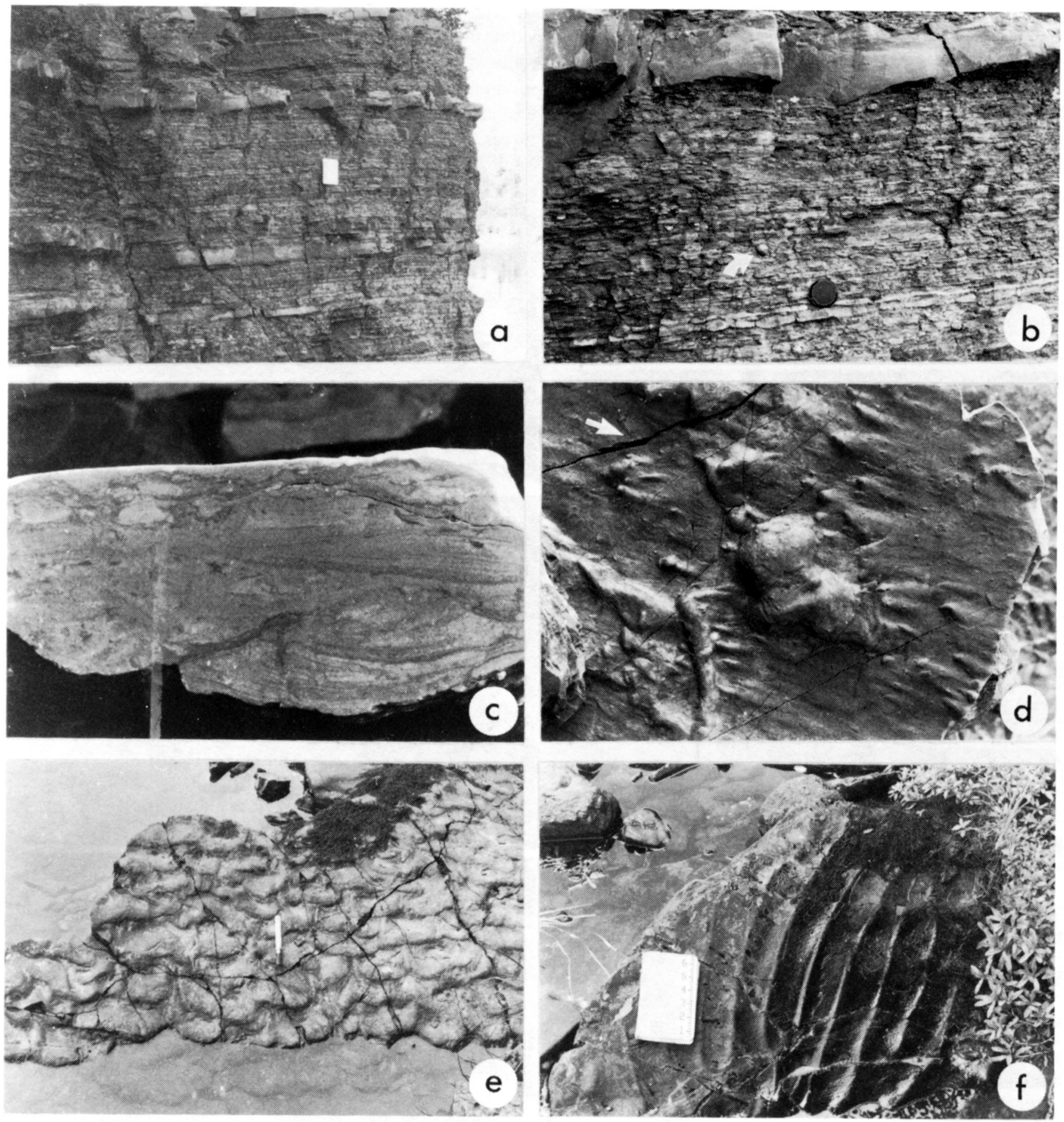

Fig. 5. Facies KS3 at Hammond River. (a) Typical lithology of the facies exhibiting bioturbated shale and siltstone interbedded with non-bioturbated sharp and erosive based sandstone beds. Notebook is $19 \mathrm{~cm}$ in length. (b) Close-up of a part of (a). Within the bioturbated portion, note the thin non-bioturbated sandstone layers below the lens cap. Arrow points to a Palaeophycus or Trichophycus burrow. Lens cap is $5.5 \mathrm{~cm}$ in diameter. (c) Polished specimen from near the top of the facies exhibiting intense obliteration of primary fabrics by bioturbation. Specimen is $4.7 \mathrm{~cm}$ thick. (d) Flute marks, loads and rare Palaeophycus burrows on the sole of a sandstone bed. Arrow indicates direction of palaeocurrent. (e) Linguoid ripple marks on an upper bedding surface. Marker is $15 \mathrm{~cm}$ long. (f) Sharp crested symmetrical rarely bifurcating ripple marks on an upper bedding surface. Notebook is $19 \mathrm{~cm}$ long.

tional wave-formed cross-lamination (Fig. 6e).

(v) Wavy lamination which passes vertically into unidirectional ripple cross-lamination and then into bidirectional waveformed cross-lamination (Fig. 6f).

(vi) Unidirectional ripple cross-lamination passing verti- cally into wavy lamination, with some small sets of crosslamination, which passes vertically into ripple drifted lamination and finally into in-phase or sinusoidal ripple lamination (Fig. 6g).

(vii) Broadly wavy lamination with some cross-laminated sets specifically preserved in the lower portion passing upward 


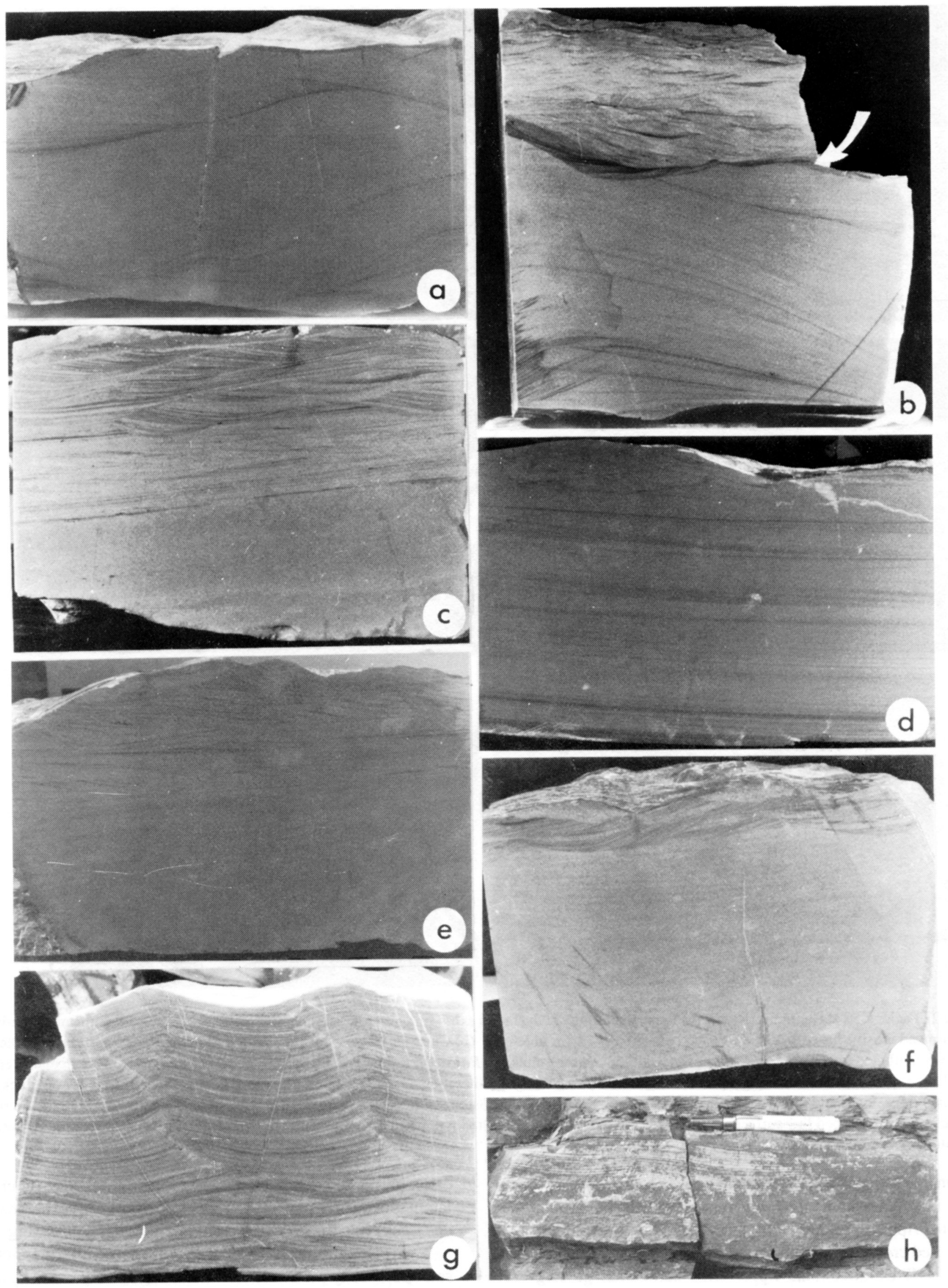


into a different set of wavy lamination (Fig. 6h).

Because of exposure difficulties the quantitative importance of these categories is difficult to evaluate. Nevertheless, types (i), (vi) and (vii) preferentially occur in the lower levels of facies KS3 and all the other types in the upper horizons but without any preferred or systematic vertical distribution. Additionally, there is no apparent relationship between bed thickness and internal organization. Flute marks are not observed to occur in types (vi) and (vii), but may occur in all other categories and are more typically associated with types (ii) and (iv). Amalgamation of the sandstones, as revealed by internal erosion surfaces in several polished slabs of apparently single beds, is also possible. Several of the categories outlined above may therefore conceivably represent composite beds, but this is obviously impossible to realistically assess quantitatively. Nevertheless, in qualitative terms, in the Hammond River section, where the facies is best exposed, the apparent relative abundance, in decreasing order, is as follows: types (iv), (iii), (ii), (i), (v), (vi), and (vii).

In the interbedded bioturbated beds, intense biogenic reworking has almost completely obliterated primary depositional fabrics with the exception of thin sandstone layers in which small-scale cross-lamination is rarely preserved. In these interbedded bioturbated beds, horizontal to slightly inclined burrows are commonly present. Most of the trace fossils are generally unrecognizable as the fabric is extremely complex and mottled (sensu Moore and Scruton, 1957). However, the trace fossil Palaeophycus, which in some cases is more than $30 \mathrm{~cm}$ long, is very common on sandstone soles. In addition, examples of poorly preserved ?Cruziana, ?Trichophycus and Teichichnus were observed.

\section{Interpretation}

Based on the previously outlined criteria proposed by Hunter and Clifton (1982) for the recognition of storm-related deposits, it is considered that the thicker-bedded sandstone beds of facies $\mathrm{KS} 3$, like those of facies KS1 and KS2, are storm-related. Of interest, however, particularly with respect to the depositional environment of the facies, is the considerable variation of internal organization of the sandstones. This variation presumably reflects a number of inter-related variables such as the strength, duration and frequency of storms, sediment content and its consistent or variable nature, depositional environment and distance from source, etc., (cf. Hurst and Pickerill, 1986).

With respect to depositional environment, the presence in some units of small-scale hummocky cross-stratification (HCS) (type $\mathrm{i}$ ), which is considered by many workers as diagnostic of storm activity (e.g., Hamblin and Walker, 1979; Cant, 1980; Dott and Bourgeois, 1982; Moore and Hocking, 1983; Mount, 1982; Duke, 1985), is meaningful. Most research on HCS suggests it to be a bedform produced in less than $30 \mathrm{~m}$ water depth (Swift $e t$ al., 1983) though it does have a reported range from $<2 \mathrm{~m}$ (Hunter and Clifton, 1982; Greenwood and Sherman, 1986) to up to at least $80 \mathrm{~m}$, Campbell (in Dott and Bourgeois, 1982) and possibly even $500 \mathrm{~m}$ (Prave, 1985). Notably, the structure in facies KS3 is not common but its presence does indicate deposition of the sandstone layers above storm wave base. Sandstones of types (iv) and (v) also possess wave rippled upper horizons suggesting deposition above wave base.

The intemal organization of type (vi) beds is very intriguing but may be described by using the terminology of Jopling and Walker (1968), from base to top, as follows: type C ripple drift, transitional from type $C$ to type $B$ ripple drift with crosslaminated sets, transitional type B ripple drift to sinusoidal, and sinusoidal ripple lamination. Jopling and Walker (1968) suggested that similar varieties of lamination as described above were all produced by unidirectional currents, the primary controlling factor being the ratio of suspended to traction load. However, in the present examples, the similarity of sediments in all the units suggests that the primary controlling factor in this particular case was hydrodynamic and that waning upward energy conditions from current-dominated through combined current and wave to wave-dominated occurred. Sandstones of type (vii) similarly suggest combined wave and current action in their lower portions (similar to the second unit of type (vi)) and a dominance of wave activity in their upper parts, presumably a result of modification by subsiding storm waves.

In contrast to the sandstones discussed above, those of types (ii) and (iii) exhibit no evidence of wave activity. Instead, their upper horizons are characterized by current-produced unidirectional ripples and climbing ripples. According to the model of Hamblin and Walker (1979) and Walker (1984) for clastic stormdominated shelves, such sandstones wouid therefore have been deposited below storm wave base, as their model would predict

Fig. 6. Internal organization in the sandstone beds of facies KS3. (a) Hummocky cross-stratification (type (i)). Bed is $13 \mathrm{~cm}$ thick. (b) Slab showing a possible composite bed, the arrow indicating the contact. The lower portion, which is $14 \mathrm{~cm}$ thick, exhibits typical hummocky stratification and the upper portion, which is $10 \mathrm{~cm}$ thick, bidirectional cross-laminae. (c) A sandstone bed with type (ii) internal organization. The basal massive portion passes vertically into horizontal lamination and in turn into current cross-lamination and climbing ripple lamination. The bed is $11 \mathrm{~cm}$ thick. (d) An $18 \mathrm{~cm}$ sandstone bed with type (iii) internal organization. Horizontal lamination in the lower portion passes vertically into climbing ripple lamination. (e) A $13 \mathrm{~cm}$ thick sandsone bed with type (iv) internal organization. Broadly wavy lamination passes vertically into unidirectional crosslaminae and climbing ripple laminae before passing into bidirectional wave-formed cross-laminae. (f) A $10 \mathrm{~cm}$ thick bed depicting type (v) intemal organization. Wavy-lamination passes vertically into unidirectional ripple cross-laminae and then into bidirectional wave-formed cross-lamination. (g) A $9 \mathrm{~cm}$ thick sandstone bed with type (vi) internal organization. Unidirectional ripple cross-lamination passes vertically into wavy lamination with small sets of cross-laminae which passes vertically into slightly ripple drifted lamination and finally into in-phase or sinusoidal ripple lamination. (h) Field photograph of a sandstone bed with type (vii) internal organization. Broadly wavy lamination with small cross-laminated sets in the lower portion passes vertically into a thin horizon at the top of the bed which preserves wave-formed ripples. Marker is $15 \mathrm{~cm}$ long. 
that combined wave- and current-produced structures be present between fair-weather and storm wave base. In a recent publication, Fenton and Wilson (1985) estimated that fair-weather and storm wave base were, in terms of approximate water depth, between $50 \mathrm{~m}$ and $200 \mathrm{~m}$, respectively. However, absolute values with respect to these water depths are impossible to determine in the geological record and are likely to have varied considerably even within a single environment. Thus, although it is clear that types (ii) and (iii) sandstones of this facies were deposited below storm wave base, no absolute depth of deposition can be ascertained.

Stratigraphically, the sandstone beds of facies KS3 do exhibit a broadly defined vertical pattern. Thus, individual sections, where well-exposed, exhibit an increased abundance of types (i), (iv), (v), (vi) and (vii) in their lower horizons and more of types (ii) and (iii) in their upper horizons. This, together with other evidence such as the general decrease in sandstone bed thickness upward in the facies, suggests an environmental situation characterized by gradual deepening, so that lower in the sequence individual beds were subject to both wave and current activity, whereas higher in the sequence beds were mainly subject to current activity. This situation conforms well with the interpretation that the facies is transitionally underlain and overlain, respectively, by inner- to mid-shelf subtidal shelf deposits (facies KS2) and outer shelf deposits of the overlying Silver Falls Formation of Tanoli and Pickerill (1988).

The interbedded shales, siltstones and thin sandstone beds are more enigmatic in terms of their origin. Traditionally, such interbedded finer-grained sediments associated with stormdominated shelf sequences have been considered as having been deposited during 'fair weather' conditions (e.g., Kreisa, 1981; Brenchley and Newall, 1982; Simonson, 1984; Johnson and Baldwin, 1986), though little comment has been made with respect to depositional mechanisms. Swift et al. (1986), however, have suggested that much of the finer-grained material may be the final product of storm deposition. Presumably, variation in wave and, or, current activity which could rework or winnow bottom sediment are equally as important factors as well as the availability of suspended material. It is also possible that the thin sandstone beds could represent 'distal' deposits of less severe storm activity similar to those described by many workers (e.g., Benton and Gray, 1981; Hobday and Morton, 1984; Simonson, 1984; Hurst and Pickerill, 1986). Irrespective of their origin, these sediments provided sufficient organic material for the establishment of a rich infaunal benthos, as evidenced by the extensive bioturbation now observed in the strata.

In summary, therefore, it is believed that facies KS3 was deposited on a gradually deepening subtidal shelf. Although the actual position on the shelf and the water depth per se are difficult to estimate, comparison with previously described analogues (Reineck and Singh, 1972; Howard and Reineck, 1981; Wright and Walker, 1981; Hobday and Morton, 1984; Aigner, 1985; Fenton and Wilson, 1985, and many others), together with the stratigraphic position of the facies with respect to underlying and overlying strata, suggests mid- to outer-shelf conditions.

\section{ENVIRONMENTAL SYNTHESIS}

Facies analysis suggests that during deposition of the lower part of the King Square Formation (i.e., facies KS1), although low energy shelf conditions generally prevailed, where chiefly muddy sediments accumulated, thin fine-grained sandstone beds were also introduced during periodically high energy conditions (cf. Simonson, 1984; Aigner, 1985; Brenchley, 1985). These sandstone beds generally increase in abundance and thickness stratigraphically upward towards the overlying facies KS2 of the formation. The entire facies KS1 was deposited below fairweather wave base; most was deposited below storm wave base in mid-shelf, possibly deeper, conditions but toward the contact with the overlying facies KS2 we suspect deposition occurred between storm and fair-weather wave base. Facies KS2 was deposited in a shallow wave- and storm-influenced subtidal inner- to mid-shelf environment above storm wave base. Thus, a shallowing (regressive) phase is indicated from facies KS1 into facies KS2. Facies KS2, when traced vertically into facies KS3, the uppermost portion of the King Square Formation, exhibits decreased proportions and bed thicknesses of interbedded sandstones. Facies KS3 was initially deposited above and latterly below storm wave base in a mid- to outer-shelf environment. Thus, a deepening (transgressive) phase was once again initiated during deposition of the upper portion of facies KS2.

Palaeocurrent data from the King Square Formation as exposed in the city of Saint John and on Hammond River are plotted on Figure 7. In Saint John, cross-laminated foresets are scattered but north-northeast and south-southwest trends are prominent (Fig. 7). Dispersed and oppositely directed palaeocurrents are well-documented from high energy shelf sequences similar to that of the King Square Formation (see Benton and Gray, 1981; Gray and Benton, 1982; Brenchley, 1985) and result from the complex nature of current flows in such environments (Swift et al., 1986). Strikes of symmetrical ripple crests from these strata at Saint John are also variable but exhibit a predominantly north-south trend. The observed scatter may be the result of either one or a combination of several factors: (1) variations in palaeocurrents and their different origins, viz. wave versus current or superimposition of one on the other, (2) local variations in the palaeoshoreline orientation, or (3) different than normal conditions of wave propagations for short intervals (cf. Hobday and Reading, 1972). The only examples of flute marks in the city of Saint John were observed at the base of a bed in a folded sequence at Sandy Point along the Kennebecasis River (Fig. 1) which suggest a palaeocurrent flow towards the northwest (Fig. 7).

Symmetrical wave-ripple crests from the Hammond River area strike dominantly north-northeast but some fall into the northwest and southeast quadrants (Fig. 7). All the palaeocurrent data, including cross-laminated foresets, flute marks and current ripple marks (Fig. 7) exhibit a similar pattern and consistently fall toward the west and into the northwestern quadrant.

Interpretation of these data is difficult because it is impossible to determine the exact nature of the flows responsible for 

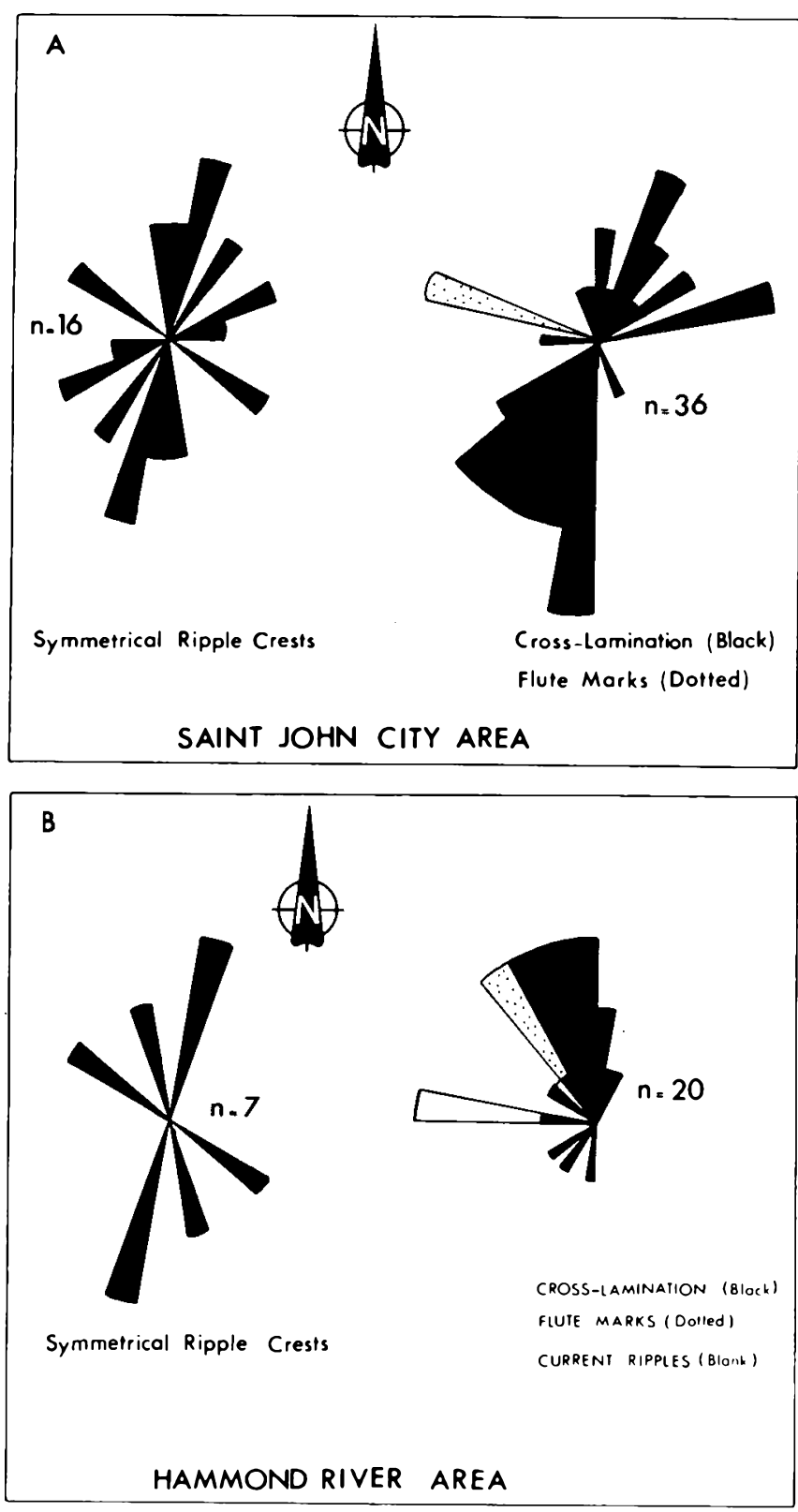

Fig. 7. Rose diagrams of palaeocurrent data in strata of the King Square Formation. (A) from localities in the city of Saint John; (B) from localities along Hammond River.

formation of the sandstone units. On present-day shelves, windforced and storm-surge ebb currents deflected by Coriolis forces to produce geostrophic currents are responsible for transportation of sands. Such geostrophic currents flow parallel or subparallel to isobaths and therefore sand is dispersed incrementally over a long time period essentially parallel to the shoreline (Swift et al., 1986). Yet, as noted by Walker (1986), there is little positive evidence in the geological record for incremental dispersal of sand, perhaps because the final storm imprint erases evidence for the long term sand transport process. Additionally, as previously noted, there is good evidence in the geological record that gravity-driven turbidity currents may have been important in emplacing such sands, with dispersal down the palaeoslope and perpendicular to isobaths. Essentially, there- fore, the palaeocurrent data must be interpreted with caution and all that can be concluded is that irrespective of their origin, the sands were derived from a broadly easterly source area. This is further reinforced on consideration of other stratigraphic units of the Saint John Group (see Tanoli, 1987).

\section{SUMMARY AND CONCLUSIONS}

(1) Upper Middle Cambrian to early Late Cambrian strata of the King Square Formation of southern New Brunswick comprise a $380 \mathrm{~m}$ thick siliciclastic sequence of interbedded finegrained sandstone and siltstone and shale. These strata were deposited on a wave-and storm-influenced shelf and represent a regressive-transgressive sequence within which three distinct lithofacies can be recognized.

(2) Facies KS1, the lowermost lithofacies, consists of up to $80 \mathrm{~m}$ of thinly interbedded sandstone and generally non-bioturbated shale which was deposited essentially below wave base in a mid-shelf, possibly deeper, environment. In its upper horizons, between its gradational transition into the overlying facies KS2, deposition may have occurred above storm wave base.

(3) Facies KS2 consists of thick-bedded sandstone and lower proportions (10 to $30 \%$ ) of bioturbated or non-bioturbated shale. The facies is the most widely exposed of the three, and wherever exposed continuously, is at least $160 \mathrm{~m}$ thick, probably more. The facies was deposited in a shallow subtidal inner-to mid-shelf environment above storm wave base.

(4) Facies KS3 consists of interbedded sandstone and bioturbated shale and siltstone which gradationally overlies facies $\mathrm{KS} 2$. Thickness is impossible to determine but at least $13 \mathrm{~m}$ are exposed at Hammond River. Sandstones of facies KS3 possess a variety of styles of internal organization as a result of currentdominated, combined current and wave or wave-dominated processes and their complex interplay acting at the time of their deposition. Facies KS3 was deposited initially between fairweather and storm wave base and latterly below storm wave base, thereby reflecting gradually deepening shelf conditions as a result of transgression.

(5) The exact nature of the currents responsible for transportation and eventual deposition of the storm-related sandstones (geostrophic flows or turbidity currents) is impossible to determine. As such, palaeocurrent data obtained from the King Square Formation, although suggestive of a broadly easterly source, must be interpreted with caution.

\section{ACKNOWLEDGEMENTS}

We wish to thank Ken Currie, Damian Nance and Ismail Patel for their active and animated discussions on many aspects of the geology of the Saint John Group. Critical reviews of the manuscript by Dag Nummedal and Roger Walker were extremely beneficial and led to a more complete understanding of operative processes on modern and ancient shelves. Technical assistance was provided by Angel Gomez and Bob McCulloch and Rose Northrup prepared the manuscript. The work was supported by funding from Natural Sciences and Engineering Research Council Grant A3857 to R.K. Pickerill and Minister of 
Education, Government of Pakistan, Scholarship to S.K. Tanoli, both of which are gratefully acknowledged.

AIGNER, T. 1982. Calcareous tempestites: storm-dominated stratification in upper Muschelkalk limestones (middle Triassic, SWGermany). In Cyclic and event stratification. Edited by G. Einsele and A. Seilacher. Springer-Verlag, New York, pp. 180-198.

- 1985. Storm depositional systems: dynamic stratigraphy in modern and ancient shallow-marine sequences. Lecture Notes in Earth Sciences, 3, Springer-Verlag, New York, 174 p.

ALLEN, J.R.L. 1984. Sedimentary structures: their character and physical basis. Developments in Sedimentology 30. Elsevier, Amsterdam, Oxford, New York, Toronto, 663 p.

1985. Wrinkle marks: an intertidal sedimentary structure due to aseismic soft-sediment loading. Sedimentary Geology, 41, pp. $75-95$.

ANKETELL, J.M., CEGLA, J., and DZULYNSKI, S. 1970. On the deformational structures in systems with reversed density gradients. Rocznik Polskiego Towarzystwa Geologicznego, 40, pp. 3 30.

BANKS, N.L. 1973. Innerelv Member: Late Precambrian marine shelf deposit, East Finnmark. Norges Geologiske Undersokelse, 288, pp. 7-25.

BENTON, M.J. and GRAY, D.I. 1981. Lower Silurian distal shelf storm-induced deposits in the Welsh Borders: sediments, tool marks and trace fossils. Joumal of the Geological Society of London, 138, pp. 675-694.

BOURGEOIS, J. 1980. A transgressive shelf sequence exhibiting hummocky stratification: the Cape Sebastian sandstone (Upper Cretaceous), southwestem Oregon. Joumal of Sedimentary Petrology, 50, pp. 681-702.

BRENCHLEY, P.J. 1985. Storm influenced sandstone beds. Modern Geology, 9, pp. 369-396.

BRENCHLEY, P.J. and NEWALL, G. 1982. Storm-influenced innershelf sand lobes in the Caradoc (Ordovician) of Shropshire, England. Joumal of Sedimentary Petrology, 52, pp. 1257-1269.

BRENCHLEY, P.J., NEWALL, G., and STANISTREET, I.B. 1979. A storm surge origin for sandstone beds in an epicontinental platform sequence, Ordovician, Norway. Sedimentary Geology, 22, pp. 185-217.

BRENCHLEY, P.J., ROMANO, M., and GUTIERREZ-MARCO, J.C. 1986. Proximal and distal hummocky cross-stratified facies on a wide Ordovician shelf in Iberia. In Shelf sands and sandstones. Edited by R.J. Knight and J.R. McLean. Canadian Society of Petroleum Geologists, Memoir 11, pp. 241-255.

BRENNER, R.L. and DAVIES, D.K. 1973. Storm-generated coquinoid sandstone: genesis of high energy marine sediments from the Upper Jurassic of Wyoming and Montana. Geological Society of America Bulletin, 84, pp. 1685-1698.

CANT, D.J. 1980. Storm-dominated shallow marine sediments of the Arisaig Group (Silurian-Devonian) of Nova Scotia. Canadian Journal of Earth Sciences, 17, pp. 120-131.

DE RAAF, J.F.M., BOERSMA, J.R., and VAN GELDER, A. 1977. Wave-generated structures and sequences from a shallow marine succession, Lower Carboniferous, County Cork. Sedimentology, 24, pp. $451-480$.

DOTT, R.H., JR. and BOURGEOIS, J. 1982. Hummocky stratification: significance of its variable bedding sequences. Geological Society of America Bulletin, 93, pp. 663-680.

DUKE, W.L. 1985. Hummocky cross-stratification, tropical hurricanes, and intense winter storms. Sedimentology, 32, pp. 167-194.

-1987. Hummocky cross-stratification, tropical hurricanes, and intense winter storms. Reply. Sedimentology, 34, pp. 344-359.

FENTON, M.W. and WILSON, C.J.L. 1985. Shallow-water turbidites: an example from the Mallacoota Beds, Australia. Sedimentary Geology, 45, pp. 231-260.

GOLDRING, R. and BRIDGES, P. 1973. Sublittoral sheet sandstones. Journal of Sedimentary Petrology, 43, pp. 736-747.

GRAY, D.I. and BENTON, M.J. 1982. Multidirectional Palaeocurrents as Indicators of Shelf Stonn Beds. In Cyclic and Event Stratification. Edited by G. Einsele and A. Seilacher. Springer Verlag, Berlin, Heidelberg, New York, pp. 350-353.

GREENWOOD, B. and SHERMAN, D.J. 1986. Hummocky crossstratification in the surf zone: flow parameters and bedding genesis. Sedimentology, 33, pp. 33-45.

HAMBLIN, A.P. and WALKER, R.G. 1979. Storm-dominated shallow marine deposits: the Fernie-Kootenay (Jurassic) transition, southern Rocky Mountains. Canadian Journal of Earth Sciences, 16, pp. 1673-1689.

HANDFORD, C.R. 1986. Facies and bedding sequences in shelfstorm-deposited carbonates - Fayetteville Shale and Pitkin Limestone (Mississippian), Arkansas. Journal of Sedimentary Petrology, 56, pp. 123-137.

HARMS, J.C., SOUTHARD, J.B., SPEARING, D.R., and WALKER, R.G. 1975. Depositional environments as interpreted from primary sedimentary structures and stratification sequences. Society of Economic Paleontologists and Mineralogists, Short Course, 2, $161 \mathrm{p}$.

HAYES, A.O. and HOWELL, B.F. 1937. Geology of Saint John, New Brunswick. Geological Society of America, Special Paper 5, 146 p.

HAYES, M.O. 1967. Hurricanes as geological agents: case studies of Hurricanes Carla, 1961, and Cindy, 1963. Report of investigation, 61, Bureau of Economic Geology, The University of Texas, Austin. $56 \mathrm{p}$.

HOBDAY, D.K. and READING, H.G. 1972. Fair weather versus storm processes in shallow marine sand bar sequences in the late PreCambrian of Finnmark, North Norway. Journal of Sedimentary Petrology, 42, pp. 318-324.

HOBDAY, D.K. and MORTON, R.A. 1984. Lower Cretaceous shelf storm-deposits, northeast Texas. In Siliciclastic shelf sediments. Edited by R.W. Tillman and C.T. Siemers. Society of Economic Paleontologists and Mineralogists, Special Publication 34, pp. 205-213.

HOWARD, J.D. and REINECK, H.E. 1981. Depositional facies of a "high energy" beach-to-offshore sequence and their comparison with a low energy sequence. American Association of Petroleum Geologists Bulletin, 65, pp. 807-830.

HUNTER, R.E. and CLIFTON, H.E. 1982. Cyclic deposits and hummocky cross-stratification of probable storm origin in Upper Cretaceous rocks of Cape Sebastian area, southwestem Oregon. Journal of Sedimentary Petrology, 52, pp. 127-144.

HURST, J.M. and PICKERILL, R.K. 1986. The relationship between sedimentary facies and faunal associations in the Llandovery siliciclastic Ross Brook Formation, Arisaig, Nova Scotia. Canadian Journal of Earth Sciences, 23, pp. 705-726.

JOHNSON, H.D. and BALDWIN, C.T. 1986. Shallow siliciclastic seas. In Sedimentary environments and facies, second edition. Edited by H.G. Reading. Blackwell Scientific Publications, Oxford, pp. 229-282.

JOPLING, A.V. and WALKER, R.G. 1968. Morphology and origin of ripple-drift cross lamination, with examples from the Pleistocene of Massachusetts. Journal of Sedimentary Petrology, 38, pp. 971984. 
KLEIN, G. de V. and MARSAGLIA, K.M. 1987. Hummocky crossstratification, tropical hurricanes, and intense winter storms. Discussion. Sedimentology, 34, pp. 333-337.

KREISA, R.D. 1981. Storm-generated sedimentary structures in subtidal marine facies with examples from the Middle and Upper Ordovician of southwestem Virginia. Journal of Sedimentary Petrology, 51, pp. 823-848.

KUMAR, N. and SANDERS, J.E. 1976. Characteristics of shoreface deposits: modem and ancient examples. Journal of Sedimentary Petrology, 46, pp. 145-162.

McCAVE, I.N. 1985. Recent shelf clastic sediments. In Sedimentology: Recent developments and applied aspects. Edited by P.J. Brenchley and B.P.J. Williams. Blackwell Scientific Publications, Oxford, pp. 49-65.

MOORE, D.G. and SCRUTON, P.C. 1957. Minor internal structures of some recent unconsolidated sediments. American Association of Petroleum Geologists Bulletin, 41, pp. 2723-2751.

MOORE, P.S. and HOCKING, R.M. 1983. Significance of hummocky cross-stratification in the Permian of the Carnarvon Basin, Western Australia. Journal of the Geological Society of Australia, 30, pp. 323-331.

MORTON, R.A. 1981. Formation of storm deposits by wind-forced currents in the Gulf of Mexico and the North Sea. In Holocene marine sedimentation in the North Sea Basin. Edited by S.D. Nio et al. International Association of Sedimentologists, Special Publication 5, pp. 385-396.

MOUNT, J.F. 1982. Storm-surge-ebb origin of hummocky crossstratified units of the Andrews Mountain Member, Campito Formation (Lower Cambrian), White-Inyo mountains, eastem Califormia. Joumal of Sedimentary Petrology, 52, pp. 941-958.

NELSON, C.H. 1982. Modem shallow-water graded sand layers from storm surges, Bering Shelf: a mimic of Bouma sequences and turbidite systems. Journal of Sedimentary Petrology, 52, pp. 537 545.

PICKERILL, R.K. 1982. Cambrian medusoids from the Saint John Group, southem New Brunswick. In Current Research, Part B, Geological Survey of Canada, Paper 82-1B, pp. 71-76.

PRAVE, A.R. 1985. Can hummocky cross-stratification be formed below effective wave base? (abstract). Geological Society of America, Abstracts with Programs, 17, p. 693.

REINECK, H.E. and SINGH, I.B. 1972. Genesis of laminated sand and graded rhythmites in storm-sand layers of shelf mud. Sedimentology, 18, pp. 123-129.

- 1980. Depositional sedimentary environments, second edition. Springer-Verlag, New York, 549 p.

REINECK, H.E. and WUNDERLICH, F. 1968. Classification and origin of flaser and lenticular bedding. Sedimentology, 11, pp.99104.

RICE, D.D. 1984. Widespread, shallow-marine, storm-generated sandstone units in the upper Cretaceous Mosby Sandstone, central
Montana. In Siliciclastic shelf sediments. Edited by R.W. Tillman and C.T. Siemers. Society of Economic Paleontologists and Mineralogists, Special Publication 34, pp. 143-161.

SIMONSON, B.M. 1984. High-energy shelf deposit: early Proterozoic Wishart Formation, northeastern Canada. In Siliciclastic shelf sediments. Edited by R.W. Tillman and C.T. Siemers. Society of Economic Paleontologists and Mineralogists, Special Publication 34, pp. 251-268.

STANLEY, D.J., ADDY, S.K., and BEHRENS, E.W. 1983. The mudline; variability of its position relative to shelfbreak. In The shelfbreak; critical interface on continental margins. Edited by D.J. Stanley and G.T. Moore. Society of Economic Paleontologists and Mineralogists, Special Publication 33, pp. 279-298.

SWIFT, D.J.P., FREELAND, G.L., and YOUNG, R.A. 1979. Time and space distribution of megaripples and associated bedforms, Middle Atlantic Bight, North American Atlantic shelf. Sedimentology, 26, pp. 389-406.

SWIFT, D.J.P., FIGUEIREDO, A.G., JR., FREELAND, G.L., and OERTEL, G.F. 1983. Hummocky cross-stratification and megaripples: a geological double standard? Journal of Sedimentary Petrology, 53, pp. 1295-1317.

SWIFT, D.J.P., HAN, G., and VINCENT, C.E. 1986. Fluid process and sea-floor response on a modern storm-dominated shelf: middle Atlantic shelf of North America. Part 1: The storm current regime. In Shelf sands and sandstones. Edited by R.J. Knight and J.R. McLean. Canadian Society of Petroleum Geologists, Memoir 11, pp. 99-119.

TANOLI, S.K. 1987. Stratigraphy, sedimentology, and ichnology of the Cambrian-Ordovician Saint John Group, southern New Brunswick, Canada. Unpublished Ph.D. thesis, University of New Brunswick, 2 volumes, 436 p.

TANOLI, S.K. and PICKERILL, R.K. 1988. Lithostratigraphy of the Cambrian-Early Ordovician Saint John Group, southern New Brunswick. Canadian Journal of Earth Sciences, 25, pp. 669-690.

WALKER, R.G. 1983. Cardium Formation 1. "Cardium, a turbidity current deposit" (Beach, 1956); a brief history of ideas. Bulletin of Canadian Petroleum Geology, 31, pp. 205-212.

- 1984. Shelf and shallow marine sands. In Facies models, second edition. Edited by R.G. Walker. Geoscience Canada, Reprint Series, 1, pp. 141-170.

. 1986. Wave-dominated shelves - a geological point of view. In Shelf sands and sandstones. Edited by R.J. Knight and J.R. McLean. Canadian Society of Petroleum Geologists, Memoir 11, p. 344.

WRIGHT, M.E. and WALKER, R.G. 1981. Cardium Formation (Upper Cretaceous) at Seebe, Alberta-storm transported sandstones and conglomerates in shallow marine depositional environments below fair-weather wave base. Canadian Journal of Earth Sciences, 18, pp. 795-809. 